\title{
НОРМАТИВНО-ПРАВОВІ ОСНОВИ ЗАБЕЗПЕЧЕННЯ ВЗАЕМОДІЇ ОРГАНІВ ВЛАДИ 3 ГРОМАДЯНАМИ В КРАЇНАХ ЄВРОПЕЙСЬКОГО СОЮЗУ
}

Лізаковська C. В., канд. наук 3 держ. упр., доцент, Військово-морська академія імені Героїв Вестерплатте в Гдині, Польща

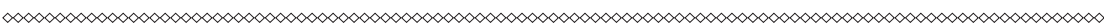

Розглядаються предмет європейського правового регулювання в сфері співпраці влади з громадянами, європейське право у широкому та вузькому розумінні щзодо регулювання взаємовідносин вищезазначених суб 'сктів.

В статті розглядається специфіка права Європейського Союз, яка передбачає існування системи правових принципів, провідним 3 яких є принции прямої дії права ЄС в державах-членах.

В опрацюванні звертається увага на предмет правового регулювання права $С C$, а саме суспільні відносини, щзо сформувалися в процесі комплексної інтеграції європейських держав, а також ті відносини, щуо потребують створення, зміни чи розвитку з метою оптимізації інтеграції в межах $Є C$.

Досліджуються суб'єкти та принциии права СС, первинні та вторинні джерела права Свросоюзу, європейські документи, спрямовані на поширення та ефективність залучення громадськості до вирішення актуальних сочіально-економічних питань життєдіяльності громад.

Звертається увага в статті на наступний факт - громадські організації в Свропейському Союзі мають регіональний вимір, оскільки реалізують свої иілі та завдання в межах багаторівневої широкої системи управління наддержавних представницьких органів.

Проаналізовано основні принциипи взаємодї органів влади ЄС із інститутами громадянського суспільства, які зазначені у Кодексі належної практики громадської участі у прочесі прийняття рішень. Окреслено стандарти доступу громадян до публічної інфор- 
мації та надання інформації громадянам в країнах Свропейського Союзу щуодо використання фінансів органами публічної влади.

Ключові слова: кооперачія, влада, громадські організації, громадськість, діалог, договір, СС, закон, інформування, кодекс, право, правовий акт, принципи, прозорість, рівність, рішення, солідарність, иінності, участь.

Аналіз останніх досліджень та публікацій. Науковий аналіз розвитку нормативно-правових положень, сформульованих в нормативній базі Європейського Союзу, які регулюють взаємодію органів публічної влади та громадських організацій, присвячені наукові праці таких дослідників як Л. Воронько, С. Гладкова, Т. Гусаченко, Ф. Дессе, С. Загороднюк, Л. Ітельсон, П. Крайник, А. Куюмджиєва, Е. Лундберг, О. Оболенський, О. Палій, О. Приходько, В. Роман, В. Сухенко, С. Сьомін, І. Ткаченко, О. Турій, О. Тюріна, Б. Фінке, А. Халецький, Е. Хейдбредер, А. Чемерис та ін.

Метою статті $\epsilon$ аналіз нормативно-правових джерел щодо забезпечення взаємодії органів влади з громадськістю в країнах Європейського Союзу.

Формулювання цілей статті (постановка завдання). У процесі висвітлення, дослідження та аналізу нормативно-правової бази забезпечення взаємодії органів влади з громадськістю в країнах $\mathrm{CC}$ були сформульовані наступні завдання:

- окреслити предмет механізму правового регулювання в $\mathrm{CC}$, європейське право у широкому та вузькому розумінні;

- визначити суб'єкти та принципи права СС щодо кооперації влади з громадянами;

- висвітлити європейські документи, які спрямовані на інтегральну взаємодію вищезазначених суб'єктів та ефективність залучення громадськості до публічних справ;

- представити основні принципи взаємодії органів влади $\mathrm{CC} \mathrm{із}$ громадськими інституціями, які містяться у Кодексі належної практики громадської участі у процесі прийняття рішень;

- окреслити стандарти відкритості та надання інформації громадськості в країнах Свропейського Союзу. 
Виклад основного матеріалу дослідження. Аналіз нормативно-правових основ забезпечення взаємодії органів публічної влади з громадянами в країнах $\mathrm{CC} \mathrm{варто} \mathrm{розпочати} \mathrm{з} \mathrm{розгляду} \mathrm{основ} \mathrm{права}$ Свропейського Союзу. Зазначимо, що європейське право - це комплекс нормативно-правових положень, які сформульовані у відповідних актах європейських інституцій. Тобто у широкому розумінні це регіональне право (не міжнародне, оскільки останнє стосується в більшості країн світу, наприклад, міжнародне публічне право), яке імплементоване на європейському рівні та норми національних правових систем країн-членів СС. Свропейське право у вузькому розумінні варто розглядати через призму Лісабонського договору, що об'єднує Співтовариство. Із набуттям СС міжнародної правосуб'єктності і набуттям статусу суб' єкта міжнародних відносин, який має право підписувати міжнародні договори, під європейським правом, у вузькому розумінні, можна визначати правову систему Європейського Союзу, що володіє власними особливостями, які й визначають їі специфічний статус як правової системи, що існує поряд 3 міжнародним та національним системами права.

На думку доцента О. Тюріної, утвердження європейського права проходило через поступове визнання права суспільною цінністю, спрямованою на забезпечення прогресу та стабільності в громадянському суспільстві. Це відбувалося під впливом певних історико-культурних чинників, серед яких, зокрема, - відродження ідеї ролі права як регулятора суспільних відносин, як засобу соціальної організації, як втілення норм розуму. Відтак європейське право - це, насамперед, певний історико-культурно-цивілізаційний феномен [8, c. 50].

Характеризуючи джерела права Свропейського Союзу, перш за все варто зазначити, що джерела права СС - це сукупність норм права $\mathrm{CC}$, які прийнято поділяти на первинні та вторинні джерела права Євросоюзу.

Джерела первинного права Європейського Союзу:

- всі установчі договори про СС;

- всі договори про вступ до ЄС;

- акт про прямі вибори до Парламенту СС; 
- Хартія Свропейського союзу про основні права від 2000 р.

Важливо підкреслити, що установчі акти займають в ієрархії вищу сходинку серед джерел права ЄС. До їх числа належать:

- Паризький договір від 1951 р. про створення СОВС (Свропейське об'єднання вугілля та сталі);

- Римські договори від 1957 р., що поклали початок існуванню Євроатому і Європейського економічного співтовариства (СЕС);

- Сдиний європейський акт від 1986 р., який передбачав створення єдиного ринку;

- Маастрихтський договір про створення Свропейського Союзу 1992 p.;

- Амстердамський договір від 1997 р.

До джерел вторинного права Свропейського Союзу відносять:

- регламенти - нормативно-правові акти загального характеру, і є обов'язкові для виконання всіма суб'єктами права ЄС і є актами прямої дії;

- директиви - вид нормативно-правового акту, в якому вказуються мета і результати, які повинні бути досягнуті, однак національній владі надається право самій визначати, в якій формі чи за допомогою яких процедур і механізмів ця мета може бути досягнута;

- рекомендації та висновки - джерело праве, яке не обов'язковим до виконання, але вони мають враховуватися при прийнятті рішень;

- рішення - правові акти, які мають індивідуальний характер, обов'язкові для своїх адресатів, як правило, стосуються спеціальних, вузьких технічних питань і обов'язкові тільки для тих суб'єктів, яким вони адресовані.

Отже, право Свропейського Союзу - це сукупність нормативно-правових норм, що регулюють процеси європейської інтеграції, функціонування інституцій СС та реалізацію ними завдань на європейському рівні.

Предметом правового регулювання права СС є суспільні відносини, що сформувалися в процесі довготривалої комплексної інтеграції країн Західної, Центральної Свропи, а також ті суспільні відносини, що потребують створення, зміни чи розвитку з метою оптимізації інтеграції держав в межах кордонів СС. 
Доцільно визначити такі категорії як суб'єкти та принципи права ЄС.

Основними суб'єктами права Європейського Союзу визнаються фізичні особи, юридичні особи, держави, Свропейський Союз та його інституції.

Фізичні особи - суб' єкти права СС:

- громадяни $\mathrm{CC} \mathrm{(фізичні} \mathrm{особи,} \mathrm{що} \mathrm{мають} \mathrm{громадянство} \mathrm{дер-}$ жав - членів (C);

- іноземні громадяни;

- особи без громадянства.

Юридичні особи - суб'єкти права ЄС:

- юридичні особи, створені за законодавством держав-членів;

- юридичні особи, створені відповідно до законодавства ЄС;

- іноземні юридичні особи, що здійснюють свою діяльність у межах Свропейського Союзу.

Держави - суб'єкти права СС:

- держави - члени СС та їх компетентні органи;

- іноземні держави (треті країни), із виокремленням держав-сусідів [8, с. 50].

Право Європейського Союзу має власну специфіку, яка полягає в тому, що існує система правових принципів. Провідними принципами права Європейського Союзу є принцип верховенства права Європейського Союзу, тобто джерела права держав-членів повинні бути адаптовані до правових норм ЄС.

Сутність принципу верховенства права Європейського Союзу полягає в тому, що норми національного права держав-членів не повинні суперечити нормам права СС. Варто зазначити, що нормативно-правові документи СС повинні бути ратифіковані державами-членами. Принцип верховенства права Свропейського Союзу був сформульований в установчих договорах ЄС. Доцільно зазначити, що нормативно-правові акти країн-членів $\mathrm{CC}$, і перш за все конституції, повинні бути збіжні з нормативною базою Європейської спільноти.

У системі принципів права ЄС провідне місце посідають загальні принципи права. Перш за все, загальні принципи права ви- 
ражають основи справедливості: принцип заборони зворотної сили закону (даний принцип походить від принципу Римського права), заборони подвійного покарання за одне правопорушення. Важливо підкреслити: принципи міжнародного права, які є загальновизнаними і встановленими Статутом Організації Об'єднаних Націй як норми імперативного характеру - обов'язкові до виконання (прямо наказують правила поведінки), наприклад, заборона торгівлі людьми, заборона піратства, сумлінне виконання міжнародних обов'язків, неприпустимість застосування сили чи погрози силою, мирне вирішення спорів та конфліктів тощо.

До загальних правових принципів права Свропейського Союзу належать такі як:

- загальні принципи конституційного устрою Європейського Союзу, які представлені у Маастрихтському договорі: принцип свободи, принцип демократії, принцип верховенства права;

- принцип поваги фундаментальних прав людини, що зазначений у Хартія Європейського союзу про основні права (була проголошена 07.12.2000 р. і в подальшому включена до Лісабонського договору від 13.12.2007 р.);

- принцип рівності, який передбачає юридичну рівність суб'єктів права СС і забороняє дискримінацію за національною, статевою, віковою, сексуальною, расовою, етнічною, культурною, мовною, релігійною приналежністю), встановлений Договором про створення Свропейського Економічного Співтовариства (1957р.) і закріплений у Хартії основних прав;

- принцип пропорційності, який встановлює, що дії та рішення $\mathrm{CC}$ повинні бути своєчасними й необхідними, спрямованими на досягнення мети Союзу, а спричинені цими діями або рішеннями негативні наслідки не можуть перевищувати рівень, необхідний для досягнення поставленої мети (передбачений установчими документами ЄС);

- принцип солідарності, який означає, що країни-члени не можуть не виконувати право Спільноти, керуючись своїми національними інтересами, і повинні докладати зусиль для ефективної реалізації цілей Спільноти (визначений у Договорі про створення Європейського Економічного Співтовариства 1957 р.); 
- принцип правової певності, що встановлює заборону зворотної сили правових актів та захист законних сподівань, тобто суттєві зміни у законодавстві $€ C$ не повинні мати зворотної сили за винятком тих випадків, коли існує нагальна необхідність вдатися до таких дій;

- принцип субсидіарності, який визначає, що Європейський Союз зобов'язаний діяти в межах повноважень і цілей, передбачених договорами, тобто справи, до яких Союз не має виключної компетенції, не можуть ним реалізовуватися, поки держава-член може самостійно досягти дану мету так само ефективно, як би це міг зробити Союз (передбачений установчими договорами СС);

- принцип дотримання процесуальних прав - право особи бути заслуханою, право на належний юридичний процес, обов'язок відповідного органу наводити підстави своїх дій або рішень.

Доцільно підкреслити, що вищезазначені засади повинні дотримуватися всіма державами-членами Європейського Союзу, а також слугувати основою для діяльності інституцій ЄС. Крім того, принципи співвідносяться 3 нормативно-правовими нормами країн-членів СС [8, с. 57-58].

Право жителів населених пунктів брати участь у слуханні та прийнятті рішень, що стосуються їх власного розвитку та розвитку міст, сіл де вони проживають, закріплено на міжнародному та національному рівнях. А саме у:

- Віденській декларація ООН «Декларація про право на розвиток» вказує, що людина є основним суб'єктом процесу розвитку i повинна бути активним учасником та вигодонабувачем права на розвиток [12];

- Свропейській декларація прав міст стверджується, що мешканці європейських міст, усвідомлюючи свою відповідальність за стан міст, виявляють солідарність і беруть на себе зобов'язання домагатися забезпечення усім мешканцям міст рівних прав на правову безпеку, екологічну безпеку, можливість знайти роботу і цим забезпечити свою особисту фінансову самостійність, житло, безпечний рух транспорту, охорону здоров'я, спорт і дозвілля, можливість займатися різноманітними культурними і творчими видами діяльності, мирне співіснування різноманітних культурних, етнічних і релігійних гро- 
мад, якісну архітектуру, гармонійне життя, власне політичне життя, економічний розвиток, гармонійний розвиток (коли місцева влада прагне досягти рівноваги між економічним розвитком і охороною навколишнього середовища), широкий асортимент товарів і послуг, раціональне використання природних ресурсів, співробітництво між містами, фінансову забезпеченість, рівноправність усіх мешканців незалежно від національності, статі, віку, релігіі, матеріального і політичного становища, фізичних або психічних недоліків [13].

Країни-члени Євросоюзу відрізняються між собою формою i рівнем демократичного, економічного розвитку, а також станом соціального середовища. Крім того, історичне підгрунття становлення держав-учасниць СС, національні особливості впливають на темпи економічного розвитку, впровадження реформ тощо. Відповідно, вони застосовують різноманітні методи залучення організацій громадянського суспільства до політичного процесу.

Варто підкреслити, що «Кодекс передової практики громадської участі у процесі прийняття рішень», прийнятий Радою Свропи, містить чітко сформульоване роз'яснення і послідовність етапів залучення громадянського суспільства: інформація, консультації, діалог і партнерство. Етапи залучення («сходинки участі») розкривають широту залучення або вилучення громадськості і містять певні вказівки на глибину (поверхневий або інтенсивний характер) процесу громадської участі [2].

Кодекс належної практики громадської участі у процесі прийняття рішень визначає ключові ознаки та характеристики громадянського суспільства:

- громадянське суспільство - це арена добровільної колективної діяльності, зосередженої навколо спільних завдань, інтересів, цілей і цінностей;

- інституційні форми громадянського суспільства теоретично відрізняються від інституційних форм держави, сім’і та економічного ринку;

- на практиці межі між державою, громадянським суспільством, сім'єю та ринком часто накладаються один на одного, й носять договірний характер; 
- громадянське суспільство, як правило, охоплює широкий спектр сфер діяльності, акторів та інституційних форм з різними рівнями автономії та влади;

- громадянське суспільство складається 3 різних організацій, які зареєстровані як благодійні організації, неурядові організації розвитку, місцеві громадські групи, жіночі організації, релігійні організації, професійні асоціації, профспілки, групи взаємодопомоги, соціальні рухи, бізнесові асоціації, коаліції та адвокаційні групи [4].

Зазначена концепція практики громадської участі знайшла подальший розвиток у Білій книзі «Про європейське управління», у якій наголошується, що сформульовані важливі завдання неможливо виконати без суттєвого посилення громадської участі в політичному процесі та впровадження більш відкритих і прозорих процедур прийняття рішень [3].

Після набуття чинності поправок у тексти нормативно-правових документів, а саме Договору про Свропейський Союз і Договору про функціонування Свропейського Союзу - Лісабонський договір визначив і закріпив наступне положення - суспільний діалог є фундаментальним основним принципом і засадаю, що поширюється на всі сфери діяльності ЄС, а відкритість і громадську участь визнав базовими цінностями демократичного життя Європейської спільноти.

У документах «Демократія, управління та європейські неурядові організації» і «Побудова більш ефективного структурованого діалогу» зазначено: «Участь у процесі прийняття рішень може бути ефективною лише в разі побудови взаємної довіри не лише з точки зору громадянського суспільства, але й з боку влади. Відгуком на покладання більшої відповідальності на сектор громадянського суспільства стала пряма заява Платформи європейських соціальних НУО про те, що неурядові організації повинні «відповідати своєму мандату, бути підзвітними, прозорими та ефективними. Європейським НУО і Комісії належить спільно вивчати шляхи розробки цих та інших стандартів, а самим НУО - розробляти керівні принципи в цій сфері» [6]. Вищезазначене дає можливість зробити висновок щодо доцільності залучення недержавних організацій у процес прийняття владних рішень. 
Організація економічного співробітництва та розвитку, в свою чергу, аналогічно Кодексу належної практики Ради Свропи визначила три основні стадії відносин між владою і громадянами: інформування, консультації та активна участь (партнерство) [7].

Отже, право доступу до інформації прямо закріплене Хартією основних прав Свропейського Союзу, стаття 42 якої передбачає: «Кожний громадянин або громадянка Свропейського Союзу, чи будь-яка інша фізична або юридична особа, яка проживає або має офіційно зареєстроване місцеперебування в одній з держав-членів, має право доступу до документів інституцій, органів, установ і агентств Союзу, незалежно від носія, на якому вони зафіксовані» [1].

Окрім того, стандарти відкритості та надання інформації, які представлені в «Кодексі належної адміністративної поведінки службовців Генерального секретаріату Ради Свропейського Союзу у їхніх професійних стосунках з громадськістю» та «Кодексі належної адміністративної поведінки у стосунках з громадськістю», прийнятих Свропейською комісією. Ці кодекси встановлюють загальні стандарти надання інформації та обробки запитів громадян. Згідно з їхніми положеннями, вся інформація (якщо вона не захищена окремим законом) має надаватися без ускладнень і в повному обсязі громадянам [5].

На практиці та в реальному житті, цикл розробки політики складається $з$ трьох основних етапів: розробка політики, реалізація політики та вивчення політики. Свропейська комісія визнає важливість участі громадськості на всіх етапах та заявляє, що якість політики СС залежить від забезпечення широкої участі в усьому політичному ланцюгу - від пропозицій та концепції до реалізації. Зазначено, що протягом усього циклу розробки політики необхідно забезпечити:

- інформування громадськості, доступ до інформації щодо процесу розробки політики та іiі змісту, їі регулярне оновлення;

- розробку та дотримання прозорих, зручних процедур у процесі прийняття рішень з метою заохочення участі громадськості;

- активне залучення учасників до діалогу шляхом заслуховування їхніх пропозицій, реагування на їхні повідомлення та забезпечення зворотного зв'язку; 
- надання додаткових ресурсів (грантів, адміністративних послуг та інших товарів або послуг) таким чином, щоб учасники могли робити конструктивні внески у відповідні рішення [11, с. 20].

Підсумовуючи, можна зазначити, що питання участі громадян в розробці і реалізації публічних завдань, розуміється як процес безперервної взаємодії між різними рівнями публічної влади та громадськістю, яка включає елемент консультацій, обговорення та реалізацію спільно узгоджених рішень. Враховуючи різні етапи циклу розробки політики, інтенсивність та форма участі змінюватимуться залежно від етапу та бажаних результатів. Документи Ради Свропи та нормативно-правова база СС, а також досвід окремих країн розрізняють такі рівні участі як доступ до інформації, консультації, активна участь (партнерство). Загальним виміром залучення громадян до соціального, правового, економічного, політичного процесів на різних рівнях є участь у суспільному діалозі, який є основною формою співпраці та взаємодії влади з громадськістю [1, с. 22].

Висновки. Таким чином, право Свропейського Союзу - це сукупність нормативно-правових норм, що регулюють процеси європейської інтеграції та діяльність інституцій Європейського Союзу.

Предметом правового регулювання права ЄС є суспільні відносини, що сформувалися в процесі комплексної інтеграції європейських держав, а також ті суспільні відносини, що потребують створення, зміни чи розвитку з метою оптимізації інтеграції країн-членів в територіальних межах ЄС.

Основними суб'єктами права Свропейського Союзу визнаються фізичні особи, юридичні особи, держави, Свропейський Союз, а також його інституції та функціонери.

Процеси модернізації та оновлення системи управління в країнах-членах Європейського Союзу вимагають запровадження різних форм представництва й участі в громадському житті, у першу чергу, в таких сферах, як охорона прав людини, охорона навколишнього середовища, охорона здоров'я, енергетична безпека тощо.

Залучення громадян у процесі прийняття рішень дозволяє органам влади застосовувати нові джерела ідей, інформації і ресурсів для розробки варіантів рішень. 
Важливими та ключовими елементами успіху в процесі залучення громадян у процес формування публічних політик $є$ : інформування громади, консультації з експертами, що представляють громадськість, участь громадськості у процесі прийняття рішень та залучення до їх імплементації.

Необхідність залучення громадян до окремих елементів управління селищем, містом, державою прямо зазначено в конституціях, законах та нормативних актах європейських країн, рішеннях органів місцевого самоврядування, і правові акти гарантують вищезазначені права громадян.

\section{Стаття надійшла до редакції: 05.10.2019}

\section{LEGAL BASICS TO PROVIDE COOPERATION BETWEEN AUTHORITIES AND CITIZENS IN EUROPEAN UNION COUNTRIES}

Svitlana Lizakowska, $\mathrm{PhD}$ in Public Administration, Associate Professor of the Department Polish Naval Academy, str. Inżyniera Jana Śmidowicza 69, Gdynia, 81-103, Poland

Subject of legal regulation in the EU, European law in a general and narrow sense are considered.

The European Union law is a set of legal rules regulating the European integration processes and the European Union activity.

It is emphasized that specificity of the European Union law consists in a system of legal principles, whereof the leading ones are the principle of the European Union law prevalence over the national law of its member states and the principle of the EU law direct impact.

The main subjects of the European Union law are defined as individuals, legal entities, states, the European Union, its institutions and functionaries.

It is stated that the subject of legal regulation for the EU law is social relations formed in the process of complex integration by the European 
states, as well as those social relations that require creation, change or development in order to optimize integration within the EU.

Subjects and principles of the EU law, primary and secondary sources of the European Union law, European documents aimed at spreading and efficiency of public engagement are studied.

It is emphasized that civil society in the EU operates within the framework of a multi-tiered system of governance by supranational representative bodies. The processes of modernization within the governance system in the European Union countries demonstrate the need for greater transparency and accountability of the authorities, and therefore require the introduction of various forms of representation and participation in public life, especially in areas such as environmental protection, health care, and consumer rights protection.

The main principles of cooperation between the EU authorities and public institutions set out in the Code of Good Practice for Public Participation in Decision-Making are defined.

Documents of the Council of Europe and several legal frameworks, as well as experience of individual countries, distinguish the following levels of participation: access to information, consultation, active participation (partnership).

The key elements of success at engaging citizens in public policy formation are: informing the community, consulting with experts representing public, public participation in decision-making.

The need for authorities to engage citizens into certain elements of governing their settlement, city, country is directly stated in the constitutions, laws and regulations of the European countries, decisions by local self-government bodies.

The standards of openness and information provision in the European Union countries are studied.

Keywords: cooperation, authorities, public organizations, public, dialogue, contract, EU, regulation, informing, code, law, legal act, principles, transparency, equality, decision, solidarity, values, participation.

\section{Received: 05.10.2019}




\section{References}

1. Charter of Fundamental Rights of the European Union. Retrieved from: https://www.europarl.europa.eu > pdf > text en.

2. CIVICUS Participatory Governance Programme 2006 $\square 2008$, Concept Note, June 2006, World Alliance for Citizen Participation. Retrieved from https://www.civicus.org > downloads > PGAnne.

3. Commission of the European Communities (2001), European Governance, A White Paper, COM (2001) 428 final. Retrieved from https:// ec.europa.eu〉 sites $>$ devco〉files $>$ com.

4. Council of Europe, 2009, Code of Good Practice for Civil Participation in the Decision Making Process; the definitions given by DIFID. Civil Society Index Programme of CIVICUS. Retrieved from: http://www.dfid.gov.uk/ About $\square \mathrm{DFID} /$ Who $\square$ we $\square$ work $\square$ with $1 /$ Civil $\square$ society/ .

5. Decision of the Secretary $\square$ General of the Council/High Representative for Common Foreign and Security Policy of 25 June 2001 on a code of good administrative behavior for the General Secretariat of the Council of the European Union and its staff in their professional relations with the public. Retrieved from: https://eur-lex.europa.eu $>$ TXT $>P D F>$ uri=CEL.

6. Democracy, Governance and European NGOs, Building a Stronger Structured Dialogue, 2001, Platform of European Social NGOs. Retrieved from: https://www.globalpolicy.org $2001>0503$ engo.

7. Engaging citizens in policy making: Information, Consultation and Public Participation,2001, OECD Public Management Policy Brief, N 10. Retrieved from: https://www.gpsaknowledge.org > uploads > 2001/10 > PB-G.

8. Tiurina O.V. (2012) Osnovy prava Yevropeiskoho Soiuzu [Basics of the European Union law] Navchalnyi posibnyk. Kyiv: O. S. Lipkan [in Ukrainian].

9. Tiurina O. V. Pryntsypy prava Yevropeiskoho Soiuzu yak normatyvnyi oriientyr rozvytku pravovoi systemy Ukrainy [Principles of the European Union law as a regulatory guide for the Ukrainian legal system development] Retrieved from http://elar.naiau.kiev.ua/bitstream/123456789/4056/1/- \%20\%D0\%BC\%D 0\%B5\%D1\%80i\%D0\%B0\%D0\%BB\%D0\%B8_21.04\%20\%D0\%BE\%D1\%8 $1 \% \mathrm{D} 1 \% 82 \% \mathrm{D} 0 \% \mathrm{~B} 0 \% \mathrm{D} 0 \% \mathrm{BDi} \% \mathrm{D} 0 \% \mathrm{~B} 9 \% 20 \% \mathrm{D} 0 \% \mathrm{~B} 2 \% \mathrm{D} 0 \% \mathrm{~B} 0 \% \mathrm{D} 1 \% 80$ p455-457.pdf.

10. Turii O. V. (2018) Pravovi aspekty vzaiemodii hromadskykh orhanizatsii $\mathrm{z}$ orhanamy mistsevoho samovriaduvannia [Legal aspects of cooperation between public organizations and local self-government bodies] Kyiv: Aspekty publichnoho upravlinnia. [in Ukrainian]. 
11. Uchast hromadskosti v protsesi pryiniattia rishen. Ohliad standartiv ta praktyk u krainakh - chlenakh Rady Yevropy. m. Strasburh, traven 2016 roku [Public participation in decision-making. Review of standards and practices at the Council of Europe] Retrieved from http:// ecnl.org > uploads > 2016/08 > Overview-of-participation-standardsUkr. [in Ukrainian].

12. Videnska deklaratsiia ta Prohrama dii [The Vienna Declaration and Program of Action] Retrieved from http://zakon.rada.gov.ua/laws/show/995 504?lang=uk. [in Ukrainian].

13. Yevropeiska deklaratsiia prav mist [The European Urban Charter] Retrieved from http://www.eru.org.ua/index.php?page=1206. [in Ukrainian].

\section{Відомості про автора / Information about the Authors}

Лізаковська Світлана Володимирівна: Військово-морська академія ім. Героїв Вестерплатте, вул. Шмідовіча 69, Гдиня, 81-103, Республіка Польща.

Svitlana Lizakowska: Polish Naval Academy, str. Inżyniera Jana Śmidowicza 69, Gdynia, 81-103, Poland.

ORCID.ORG/0000-0002-1524-2673

E-mail: svema84@mail.ru 